\title{
Factors influencing Farmers' Treatments to Use Irrigation Water
}

\author{
Elgilany Ahmed*, Jamalludin Sulaiman, Saidatulakmal Mohd
}

School of Social Sciences, University Sains Malaysia, Pulau, Penang, 11800, Malaysia

\begin{abstract}
Northern region of Sudan can rightly be considered as a River Nile-born nation where a high population density (90\%) exists in the settled areas along the River Nile where agriculture production based on small-scale irrigation farms and the option of irrigation is mandatory from River Nile by pumps through the surface irrigation system. The country is below the water poverty line of 1000 cubic meter per capita per year and it may continue to be so for the foreseeable future". The competition for irrigation water and land increases resource management complexity. The aim of this research is to assess the social and economical performance of tenants and to identify options to improve irrigation system and water resource management in the State. To realize these objectives structured survey questionnaires of 70 randomly selected respondents from area of the study were interviewed beside literature. Integrated techniques involving economical and hydrological components are used to assess water use efficiency, social and economical performance of tenants in the State. The results suggest that inefficient of irrigation water use coupled with high production cost and low productivity will need attention on water management, allocation, quantities and introduction of water saving technologies.
\end{abstract}

Keywords Farmers' Treatments, Irrigation Water Use, Water Saving

\section{Introduction}

Rivers environment has not only strongly influenced the nation's overall social structure but has also dictated to a considerable degree the manner in which the development of agricultural resources affected the total economic growth of the nation. Worku (1971) stated that, water is the major critical factor which has influenced the pattern of agricultural production, the productivity of land, and the economic behavior of farmers. Hence, the development of water resources has played a primary role in the advancement of the total agrarian sector and indirectly in the economic development of the whole nation. While the average amount of water available to each country remains constant, the demand for water generally is going up steady for two important reasons, first, with expanding population, more and more water required for domestic purposes, agriculture, industry, and hydropower generation. Secondly, as the standard of living improves, the demand for water increases as well (Sheikh, 1995).In Sudan, despite, the water resource is abundant; the irrigation water is the most chronic constraint facing the agricultural sector over the country. River Nile State, the most important agricultural State in the Northern Sudan, the only possible mean of

* Corresponding author:

elgilanya@yahoo.com (Elgilany Ahmed)

Published online at http://journal.sapub.org/re

Copyright (C) 2012 Scientific \& Academic Publishing. All Rights Reserved irrigation is pumps irrigation from the Nile. The population pressure and the inefficient water use led to perpetuate the water scarcity problem. The awareness of water use efficiency not spread wide in the most of the public schemes in the State, in other words there is less stress to apply the recommended standards of crop water requirements. The area that can be commanded by pumps in feddan was significantly higher than actually cultivated one. This indicated that the capacity of those pumps was underutilized. Faki et al (2004) reported that in Northern Sudan the irrigation needs are designated in terms of numbers of irrigations, not actual quantities, and it is likely that reduction in amounts per irrigation or even number of irrigations may be possible without reducing yield. The paper undertook Elzeidab public irrigated scheme as a case study to implement the study. Elzeidab Agricultural Scheme is the oldest of the schemes belonging to the Northern Agricultural Production Corporation (NAPC) in the Northern Region when it was established in 1904. The total area of the scheme was originally 22,000 feddans, extended later by 6,900 feddans: 14,912 by Zeidab Plantation Company (ZPC), 10,006 feddans owned by the government and 4,090 feddans owned by the tenant. The scheme adopted the crop sharing arrangement based on cotton production in 1904 as an initiation policy at its establishment. In 1939, crop sharing was replaced by water rates based on the cost of pumping irrigation water. Later, in about 1952, the rates were increased on the basis that the costs of factor inputs for irrigation and administration had 
increased. Water rates have been introduced with the advancement in perennial and vegetable crops. The delivery of irrigation water for the scheme depends on pump irrigation system from the River Nile $(\mathrm{RN})$. The $\mathrm{RN}$ is the main source of irrigation water for the scheme area, particularly in the winter season, which is considered as the principle season there, while the summer and autumn "Demira" seasons rank second due to some environmental aspects. This gives advantage for the winter crops versus other seasonal crops. The farm management is fully under the tenants' control, while the government is considered as a water seller besides the preparing for agricultural policies. Although, the research work is important to assess and recommend for the socio-economic situation in the study area, but in RNS a limited research has been conducted to establish resources use system to maximize the tenants' net returns. The most predominant constraints faced irrigation water use in the State are: low water use efficiency due to lack of knowledge on the part of farmers, excessive water application rates, rising water tables and salinity, inadequate extension services and difficulties of access to existing research base high construction, operation, and maintenance costs, poor design and low quality materials. Commonly the constraints of WUE are partly of a technical nature, related to socio-economic and institutional conditions. Finally, this paper looks to the latter option(s), specifically to promote a more effective social and economical performance of Elzeidab scheme tenants through improvement of existing system and tenants conceptions towards irrigation water, hence, to increase the irrigation water productivity in the public pump schemes of RNS.

\section{Methodology}

The study was carried in Elzeidab public irrigated scheme of RNS. The crops are commonly produced under pump irrigation from the River Nile to some extend as well as from underground water. The farming system of the RNS is characterized mainly as not full-mechanized system, the winter season is considered the main season for producing cereal and legume crops, recently, the State enlarged animal production activities and oil crops. This study depends mainly on primary data from the study area, beside secondary data from relevant official sources. The method selected for primary data collection was direct personal interviewing of the sample respondents by using structural questionnaires. The primary data collected in season 2005/06 included demographic and socioeconomic characteristics of the surveyed tenants, the allocated crops through the farm area, crop production, and the factors affecting water use efficiency. Secondary data which was collected from relevant institutional sources such as River Nile State Ministry of Agriculture and Irrigation, Federal Ministry of Agriculture and Forestry, Department of Planning and Agricultural Economics, Arab Organization for Agricultural and Development (AOAD), Food and
Agriculture Organization (FAO), Agricultural Research Corporation (ARC), Khartoum, Gezira and Giessen Universities and Bank of Sudan and internet website. As precision could be achieved, stratified random sampling based on convince and flexibilities with probabilities to size was used to determine the plausible size of the targeted groups in Elzeidab public irrigated scheme of the RNS, with considering the terms of cost, time and other relevant facilities. Twice research constraints were noticed in the study area, first, the lack of infrastructure made the movement over the study area difficult, and the unavailability of transportation (except certain day(s) per week for some parts of the study area), second, some farmers were ignorant about the research work, and hence, they required more time to obtain the right information from them, moreover, some of them thought that the research work end to take taxes so they refused to be interviewed. Furthermore, numerous farmers reported that a lot of research work had been done in their areas, without tangible returns to them.

\subsection{Analytical Techniques}

To achieve stated objectives descriptive statistical and regression analysis using Cobb-Douglas production function were used. In the descriptive part of the analysis frequency distribution, graphical and statistical analysis was used. Different forms were tried to choose the best representative model. Cobb-Douglas production function analysis using (OLS) regression was used to assess the effect of the hypothesized independent variables on water use efficiency.

The calculation of the crop water requirements (CWR) of any crop requires estimation of its crop coefficient $(\mathrm{Kc})$. Kc values could be used for estimation of CWR as a product of $\mathrm{Kc} *$ ETo in the RNS as well as other similar regions of the Sudan. Recently, FAO Penman-Monteith (PM) method was developed to estimate ETo values from a hypothetical reference crop that were more consistent with the actual CWR and has been recommended by FAO as the standard method for CWR calculation designed in the software program CROP WAT4.

\section{Results and Discussion}

\subsection{Socioeconomic Characteristics of the Tenants}

The socioeconomic characteristics of the tenants are expected to have a great effect on the production process in the study area. In addition to increasing crop production and farm and family incomes, improved irrigation access significantly contributes to rural poverty reduction through improved employment and livelihood within a region (Barker et al, 2000). The main collected socioeconomic information was on tenants' education level, marital status, age, family size, family contribution on field work, years of experience, occupations in and/or out farm, distance 
between the tenants' home and field, farm size of tenants, and land tenure beside some data regarded their farm activities.

From Table (1) the major socioeconomic characteristics of Elzeidab farmers are all farmers in the sample are males and $85.7 \%$ were married and $14.3 \%$ of them were single, while the paper provided the other socioeconomic characteristics broadly as follow:

Table 1. Major socioeconomic characteristics of the surveyed tenants.

\begin{tabular}{|c|c|c|c|}
\hline No. & Indicator & Mean & STD \\
\hline 1 & Age & 39.9 & 9.8 \\
\hline 2 & Family size & 6.5 & 3.2 \\
\hline 3 & Years of experience & 19.9 & 12.3 \\
\hline 4 & Farm size & 8.2 & 6.9 \\
\hline 5 & Distance from tenants' resident to the farm & 2.7 & 3.2 \\
\hline 6 & Number of family labor & 2.0 & 1.8 \\
\hline
\end{tabular}

\subsubsection{Age of Tenants}

The average farmers age of 40 years. No doubt age is one of the farmers' demographic characteristics, which influences the quality of his/her decision and his/her attitude towards accepting new ideas and there is generally a negative correlation between a farmer's age and his/her rate of adopting innovations. The paper revealed that there were no tenants older than 61 years, tenants younger than 30 years constituted $11.4 \%$ and the age groups $30-45$ and $46-$ 60 years constituted $68.6 \%$ and $20 \%$, respectively. It's clear that younger tenants were formed the lowest percent among the scheme tenant indicating negative consequences for adopting new irrigation technologies.

\subsubsection{Family Size}

As seen from the previous table, the average family size of surveyed tenants was 7 members while the range were 15-1 members, small families constituted the highest percentage of $43 \%$ while the medium and large ones were $35.7 \%$ and $21.4 \%$, respectively. Internet report (2009) mentioned that, Sudanese extended families include uncles and cousins going back several generations. For people in the north who are farmers and herders, family status still depends on the size of the farm and herd. In settled villages, certain families hold the rights to own land. In the past, colonial governments sometimes gave powerful positions to certain families. These family groups have gradually become part of the modern political system, but traditional ideas about power and status endure. According to this background, the small family's percentage $43 \%$ indicates to low efficiency of farm operation, hence inefficiency of irrigation water use.

\subsubsection{Years of Experience in Agriculture}

Years of experience in agriculture are an important indicator to a farm output. Sarah (2007) stated that, Africa is the source of much of the world's agricultural knowledge and biodiversity. African farmers represent a wealth of innovations. This rich basis of biodiversity still exists in
Africa today, thanks to the $80 \%$ of farmers in Africa (Kenya, Ethiopia and Sudan) who continue to save seed in a range of diverse eco-systems across the continent. The average number of years of experience of surveyed tenants was about 20 years, ranging between one and 54 years, the results hints that a high cumulative experience in crop production in study area might affect positively on irrigation water use.

\subsubsection{Land Tenure}

In many countries land tenure system combines private use rights with public ownership to private economic incentives for farm household, while stopping short of allowing full land ownership and alienable rights (Bryan and Agabi, 2007).

Table (2) detects that the majority (50\%) of surveyed tenancies were rented while those owned, shared and mixed land were $27.1 \%, 2.9 \%$ and $20 \%$, respectively.

Table 2. Frequency distribution of tenants according to land tenure.

\begin{tabular}{|c|c|c|}
\hline Land tenure group & No. of tenants & Percentage \\
\hline Owned & 19 & 27.1 \\
\hline Rental & 35 & 50 \\
\hline Share & 2 & 2.9 \\
\hline Mixed & 14 & 20 \\
\hline Total & 70 & 100 \\
\hline
\end{tabular}

\subsubsection{Farm Size}

It was hypothesized that differences in amounts of irrigation water applied and time spent irrigating would exist between farms of different sizes. Differences in soil types and on-farm irrigation water turnouts also were assumed to be factors that would influence water applied and time spent irrigating. Robert et al (2004) mentioned that the farm size or the farmer's holding significantly affects crop productivity. Operated farm size rises with level of economic development, especially in the $20^{\text {th }}$ century. Thus, the survey results unveiled that the average farm size in Elzeidab scheme was 8.2 feddan per farm household with a range of 28-1 feddan, categorizes tenants' holding into small farm (owning less than 3 feddan), medium farm (owning 3-8 feddan) and large farm (owning more than 8 feddan). Last decades the RNS witnessed an increase in the numbers of farms in the smallest acreage categories grew dramatically as a result of land splits. The small size of these farms resulted from land fragmentation under private and cooperative schemes due to the inheritance laws of Islam, and recently in the public schemes due to increasing of tenant's family size constraining applying of numerous technologies implies modern irrigation system.

\subsubsection{Educational levels}

Many studies indicated that education improves the ability of farmers to appreciate the potentials of a new technology and use of modern inputs leading to a more 
efficient transfer process. Xinhaua (2001) stated that educational standards have become important factors in determining farmers' income levels.

In Sudan generally, there are two type of education, namely formal and informal. Formal education includes four levels (foundation school, high school, university and post graduate education) while informal education consists of only one level namely ' khalwa'.

The paper found that all surveyed tenants are educated where the level of education at a certain point can influence the adoption of modern technologies especially the irrigation one and improve the farm system as depicted in Figure (1).

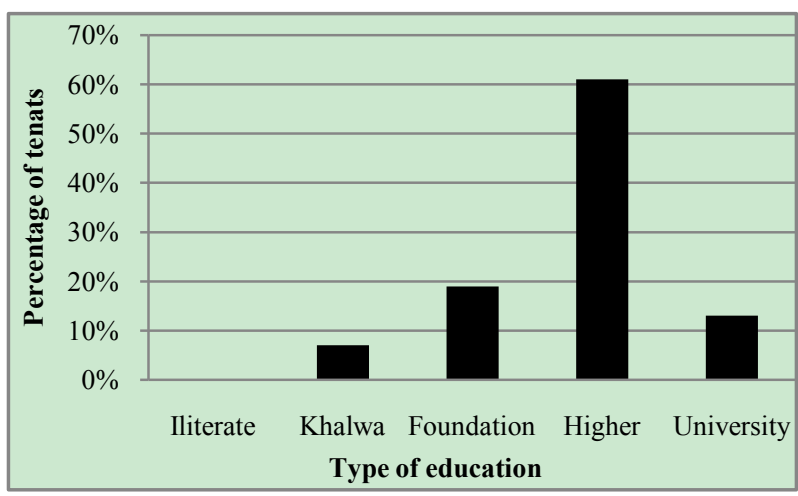

Figure 1. Frequency distribution of surveyed tenants according to the educational level

\subsubsection{Occupation}

Governmental policy for irrigated schemes in Sudan aims at keeping the tenants fully occupied with their tenancies. However, off-farm occupations among others are quite common. Rapilian (2007) from an historical perspective, the number of full-time farm operators in numerous developing countries has fallen by $24 \%$ since 1982 , while the number of part time farm operators has fallen by $18 \%$. The survey revealed that $74 \%$ were fully occupied with their tenancies while $26 \%$ of the total surveyed tenants were part-time farmers as seen from as shown in Table (3). Thus, increasing of devoted time to occupy in farm might raise the efficiency of the applied irrigation water.

Table 3. Distribution of the surveyed tenants according to occupation.

\begin{tabular}{|c|c|c|}
\hline Occupation group & No. of tenants & Percentage \\
\hline Part-time farm occupation & 18 & 26 \\
\hline Full-time farm occupation & 52 & 74 \\
\hline Total & 70 & 100 \\
\hline
\end{tabular}

\subsubsection{Contribution of Family to Farm Production}

Families can enhance their relationships and trust levels by building skills in communication, goal-setting, decisionmaking, role negotiation, problem-solving, conflict resolution and strategic planning. Rose (2007) indicated that farmers' families encompass various affiliates that offer a variety of financial products and services in addition to insurance. The majority of surveyed tenants reported that about $84.3 \%$ of their family members contribute to farm work while for a few of them $15.7 \%$ of family member didn't contribute to farm production. However, family members not only can they agree on a shared family vision with shared economic and social goals, but they also can develop a team effort. A team effort can help accomplish a shared family vision that can increase net profitability (Fetsch, 2005). The average number of family's labour of surveyed farmers was 2 members. The majority $54 \%$ of the surveyed farmer's family's labour contribute to the farm work by less than 2 members, while the contribution of family's labour share for the other categories non- family's labour, 2-4 members and greater than 4 were $15.7 \%, 28.6 \%$ and $1.4 \%$ respectively.

\subsubsection{Distance from Tenants Residence to Farm}

The distance factor is related to the point in time of a voluntary quit or a refusal of suitable work. In other words, when an individual quits work because he feels that the work is too far distant from his residence, we ordinarily consider the location of the claimant's "residence" as of the date of the separation rather than where the "residence" may have been at some earlier time (John, 1964).

The average distance from tenant's residence to farm of the surveyed tenants of Elzeidab was $2.7 \mathrm{~km}$ with maximum and minimum distances of 20 and $0.2 \mathrm{~km}$, respectively as illustrated in Table (4).

Table 4. Frequency distribution according to distance from tenant's residence to farm.

\begin{tabular}{|c|c|c|}
\hline Distance group & No. of tenants & Percentage \\
\hline Less than 3 km & 43 & 61.4 \\
\hline $3-6 \mathrm{~km}$ & 21 & 30 \\
\hline Greater than 6 km & 6 & 8.6 \\
\hline Total & 70 & 100 \\
\hline \multicolumn{3}{|c|}{ Statistics } \\
\hline Mean & 2.7 \\
\hline Std. deviation & 3.20 \\
\hline Minimum & \multicolumn{2}{|c}{} \\
\hline Maximum &
\end{tabular}

\subsection{Determination of Irrigation Water Use and Crop Water Requirements}

Sustainability of providing water for irrigation with perfect management under reliable irrigation system should achieve efficient irrigation that would further lead to expansion in the irrigated area under cultivation and consequently increases agricultural production. Thus, onfarm irrigation water use efficiency (FWUE) is defined by ICARDA (2001) as the ratio of the irrigation water required to produce a specific output level to the actual amount of water applied by farmers. With this definition FWUE may take the value of less, greater or equal to one. Less than one implies that farmers over-irrigate their crops, while the value greater than one implies that farmers under-irrigate their crops. However, if the value of the calculated FWUE is equal one, it means that farmers are fully efficient in using irrigation water because the required and applied amounts of water are equal. However, the study adopted the 
Food and Agriculture Organization (FAO) method for the calculation of irrigation water requirements; from the estimation of crop coefficient to the calculation of irrigation diversion requirements. For the crop water requirements $(\mathrm{CWr})$ under study, the procedures involve the use of the FAO program 'CropWat.4' and its associated database of climatic data for key stations around the world. From Table (5) represents the results obtained by using Crop Wat.4 program.

The paper focused on the important field crops of Elzeidab scheme namely, wheat, faba bean, chick pea, dry bean, onions, spices, vegetables, sorghum, maize, potatoes and abu70 forage. The $\mathrm{CWr}$ for the different field crops according to the predominant of climatic factors in RNS for season 2005/06 varies from crop to another as shown in the above Table. The calculation of rainfall was not considered into the above account because rainfall for RNS is variable, does not exceed $100 \mathrm{~mm}$ per year, and is unpredictable. While the approach developed in this study relies on both the State Ministry of Agriculture statistics and modeling to provide a more reliable dataset for districts and water use in irrigated schemes by combining as far as possible the data of the irrigated areas, cropping patterns, socioeconomic characteristics and irrigation system to assess the amount of water applied. The applied water amount (Wa) in equation (1) was calculated by the irrigation unit of the RNS Ministry of Agriculture and Irrigation for the State public irrigated schemes according to season $2005 / 06$ as $588 \mathrm{~m}^{3}$ /fed per watering and it consisted of about 3\% as losses for both field and perennial crops. Surface irrigation is the dominant system in Elzeidab scheme, while ground water is main source for the small private schemes overall the RNS.

\subsection{Hints of Ezeidab Surveyed Tenants' Behavior Vs. On-Farm Irrigation Water Use}

As mentioned before to assess their tenants' performance vs. on-farm water use. The general characteristics of the field crops produced in the scheme are summarized as average quantities as reported by the surveyed tenants and also they implies their behaviors in utilizing irrigation water. The study revealed that the number of irrigations and average water applied by interval for each field crops. The pattern of water application to the field crops is similar across the scheme. The distribution of crop growing period revealed that the onions remain as 141.8 day as a long age among the field crops under the study, followed by the vegetable crops as 130 day, and $114,112,112,110$ for wheat, sorghum, maize, and potato respectively, while 75 day for fodder crop as the lowest crop age. The crop ages ranged between $90-104$ days. The minimum maximum tendency number of irrigation is 4-10 irrigation for fodder and potato, vegetable, onion crops respectively, while the term of irrigation ranged between 2-5 hours for dry bean and potato crops respectively, and the maximum interval was 18.30 day for chick pea crop, while the minimum interval as 10 day for potato crop. The fixed rate of irrigation per season ranged between $39133.33 \mathrm{SD} / \mathrm{fed}-$ $10000 \mathrm{SD} /$ fed for vegetable and fodder crops respectively.

\subsection{Duration and Crop Water Applied}

The problems and constrains on the use of irrigation water level in the State as reported by many studies include: low water use efficiency due to lack of knowledge on the part of farmers, excessive water application rates, rising water tables and salinity, inadequate extension services and difficulties of access to existing research base high construction, operation, and maintenance costs, poor design and low quality materials. Commonly the constraints of WUE are partly of a technical nature, related to socioeconomic and institutional conditions. Prior to data analysis, it was hypothesized that differences in amounts of irrigation water applied and time spent irrigating would exist between area of different crops. Differences in soil types and onfarm irrigation water turnouts also were assumed to be factors that would influence water applied and time spent irrigating. The scheme's 2005/2006 accounting of water delivered does not reflect measurements in the field. The water delivery data analyzed are based on engineering estimates of canal deliveries. As known, the function of the supply canal is to carry irrigation water from the pump station through its out-let to the field, but in Elzeidab case it has more than one function; that it stores irrigation water between the head-tail of the canal as an old technique used in the scheme called night storage system. The irrigation system carries irrigation water via a system of canals according to the size (i.e. main, major, minor canals, $\mathrm{Abu}$ ishreen* and abu sita*) as shown in Table 6. Irrigation water is supplied through the scheme's irrigation network to irrigate a rotational area estimated at 16000 feddans out of the 28500 feddans. During examination of the 2005/2006 water delivery data provided by the Irrigation Department of the State ministry of Agriculture implies the average daily pumping duration of the pump station, quantity of the delivered water per irrigation and others, while the information of irrigation durations between crops were collected from the surveyed tenants of the scheme.

The scheme data included start and stop times for water deliveries, and spreadsheet functions were used to estimate total irrigation durations and irrigation durations per feddan. Irrigation duration (i.e., hours/fed/irrigation) is an indicator of field level irrigation efficiency, and is particularly useful when measurements of water applied are unreliable. The average daily pumping duration of the pump station is estimated at 10-12 hour throughout the production season; while the total quantity of the delivered water per irrigation was estimated at $8864640 \mathrm{~m}^{3}$ including water loses. This amount is devoted to the cultivated area of the scheme of 14700 feddans for both perennial and field crops when they exist simultaneously. About $78 \%$ of the total delivered water per watering was devoted to the seasonal crops with an area of 11700 fed, while the remaining amount is allocated to the perennial crops. A long duration can be 
caused by several factors, including lack of attention to irrigation practices, lack of knowledge of crop water requirements, highly permeable soils, small and/or unlined farm ditches, small farm turnouts, several users on a single delivery ditch attempting to irrigate simultaneously, and low water discharge at the farm turnout. The low discharge can be due to both poor water delivery infrastructure at the farm turnout and insufficient flows, a single factor, or a combination of several factors. Descriptive statistics and quantile analysis representing irrigation durations with comparing to the crop water applied in Figure (2) for Elzeidab field crops. The irrigation pattern is very similar for Elzeidab field crops. Differences in average irrigation duration per season exist across all field crops and striking. Figure (2) represents that dry bean is formed the lowest irrigation duration, while potatoes and onions regarded as the longest irrigation durations. Common reasons identified for long durations were the condition of the farm delivery ditches, growing period of the crop implying season's variability, and the size of the on-farm turnouts. In several cases, the water was moving so slowly through the farm delivery ditches toward the on-farm turnouts.

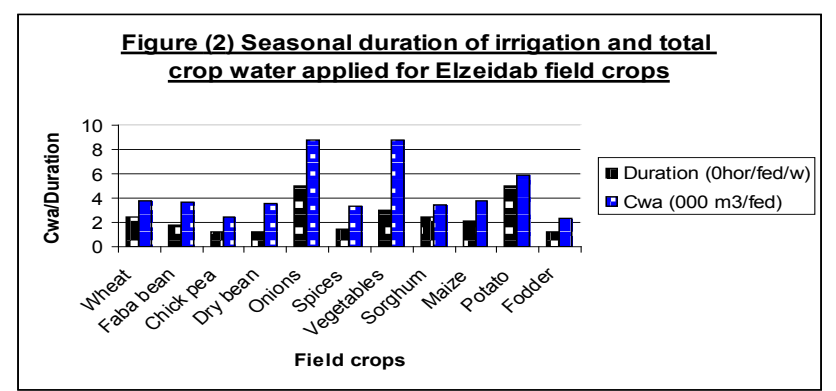

Figure 2. Seasonal duration of irrigation and total crop water applied for Elzeidab field crops.

Figure (2) also indicates the gap between the total crop water applied for the field crops and the irrigation duration implies three categories. It's clear that the greatest gap was achieved by vegetables, onions, legumes and fodder crops respectively as the first category, ranked by cereal crops as the second category including wheat, sorghum and maize as moderated crops, while the smallest gap was formed by potatoes crop as the third category. The cumulative distributions in Figure (2) consists the gap of total irrigation hours and crop water applied as discussed above under this research might suggest a correlation between them. When asked about the length of time spent irrigating their fields, several individuals complained about the bad condition of the on-farm delivery ditch from which they take their water. The scheme tenants' have no responsibility or authority for maintaining these ditches, and they noted that siltation, weeds, and breaks were factors that resulted in long irrigation durations. Overall, the levels of irrigation technology and water management found on surveyed area were extremely low, and often a consequence of inadequate irrigation design. The principal design problem found was narrow diameter farm turnouts which cannot physically deliver to the field the minimum flow necessary to rapidly push the water across the field, thus reducing both the time spent irrigating and infiltration losses during the irrigation process. On the other hand, the number of irrigation in the public irrigated scheme of RNS as described by Faki (2004) that the irrigation needs are designated in terms of numbers of irrigations, not actual quantities, and it is likely that reduction in amounts per irrigation or even number of irrigations may be possible without reducing yield. Thus, lack of knowledge about an inattention to irrigation scheduling based on crop water requirements contribute to low on-farm water use efficiency. Traditional irrigation timing practices (i.e., every 7-14 days throughout the irrigation season) contribute to over-irrigation at the beginning and end of the irrigation season, plant stress at peak crop water use periods, and can result in reductions in both crop yields and quality.

\subsection{Assessment of FWUE in Area of the Study}

FWUE of Elzeidab field crops were estimated at two levels namely, FWUE per watering and per season as shown in Table (5).

The average water application per season for field crops' area was $8820 \mathrm{~m} 3$ for onions and vegetables as the highest amounts, followed by $5880 \mathrm{~m} 3$ for potatoes, while the water amounts for the other crops ranged between 3822 and 2352 $\mathrm{m} 3$ as evident from Table (5). FWUE for some seasonal crops is relatively high given that onions, vegetables and potatoes crops are very water demanding through their growing season which took about 141, 130 and 110 days, respectively. The estimated FWUE of Elzeidab scheme indicated a wide technological gab between the required utilization and actual water application, as depicted in the above Table. According to Table (5) FWUE for the field crops per watering was found to be 0.46 for maize and spices as the highest FWUE, followed by 0.45 and 0.43 for dry bean and chickpea, respectively. It was found to be similar for wheat, faba bean and sorghum at 0.41 , while it was 0.34 for vegetables as the lowest one. This implies that farmers over-irrigated maize and spices by $54 \%$ and vegetable by $66 \%$. On the other hand, FWUE amounted to as high as 0.72 for chick pea and Abu70, followed by 0.68 , 0.64 , and 0.63 for maize, wheat and sorghum, respectively, while it was as low as 0.23 and 0.30 for vegetables and onions respectively. This implies that farmers over-irrigate their crops by $28 \%$ as the case for both chick pea and Abu70 and by $77 \%$ for vegetable crops. The results also show that farmers within the surveyed sample over-irrigated entirely their field crops. Generally in this study, the overall average FWUE was calculated as 0.40 per watering and 0.56 per season. The study also unveil that Elzeidab scheme tenants exceeded the field crops water requirements per watering by $60 \%$ and by $46 \%$ for the entire season, hinting that farmers within the surveyed sample over-irrigated entirely their field crops, suggesting high potential for irrigation water use, once FWUE is improved. This has 
important policy implication such that, improving FWUE for these crops, can contribute to the overall FWUE in the study area.

Table (6) presents the gap between the actual applied water and the water requirements for Ezeidab field crops. The average cultivated farm area in the area of study was approximately 6 feddans. The average amount of water available to this area was $28573.05 \mathrm{~m}^{3}$; while the average crop water requirements was $13432.46 \mathrm{~m}^{3}$. The estimated surplus water at $15141 \mathrm{~m}^{3}$ would be sufficient for potential extensions in the irrigated area by $6.779 \mathrm{fed}$, which would be $112 \%$ of the farm cultivated area as investigated in Figure (3). Table (6) shows the detailed results of field crops water application and requirements of Elzeidab scheme in season 2005/06. It also (Table 6) presents the $\mathrm{CWr}$ and $\mathrm{CWa}$ balance and land allocation for field crops combination that undertook by Elzeidab tenants.

Table 6. Physical gap of CWa and Wr for average cultivated farm of Elzeidab surveyed tenants.

\begin{tabular}{|c|c|c|c|c|}
\hline $\begin{array}{c}\text { Farm size } \\
(\text { fed })\end{array}$ & $\begin{array}{c}\text { cultivated } \\
\text { area (fed) }\end{array}$ & $\begin{array}{c}\text { Physical gap } \\
\text { of CWa\&Wr } \\
\left(\mathrm{m}^{3}\right)\end{array}$ & $\begin{array}{c}\text { Expected } \\
\text { extension } \\
\text { area (fed) }\end{array}$ & $\begin{array}{c}\text { Expected } \\
\text { extension } \\
\text { area (\%) }\end{array}$ \\
\hline 8.509 & 6.0149 & 15140.598 & 6.779 & 112 \\
\hline
\end{tabular}

\subsection{Yield and Water Productivity}

The profitability of adopting new irrigation technologies depends on the level of productivity improvement (Lin, 1994). The crop combination adopted by the scheme's tenants is as illustrated in Table (7). It represents the crop yields achieved by Elzeidab surveyed tenants were generally low when compared by research yields reported by the Agricultural Research and Technology Corporation (ARTC).

Yield gaps of $47 \%$ and $81 \%$ apply for dry bean and vegetable crops, respectively, indicated that much potential gap exists to increase the scheme's yields of field crops. While water productivity is defined by ICARDA in several different ways, such as pure physical productivity as the ratio of crop production $(\mathrm{kg})$ to the unit of water used $\left(\mathrm{m}^{3}\right)$ and in a monetary term is also computed in Sudanese Dinars (SD) of output per $\mathrm{m}^{3}$ of water to provide it more indicators. As depicted in Table (7) and on the basis of the previous calculations of water productivity for different crops, water productivity in technical or economic terms has important implications on the assessment and ranking the field crops.

Physical water productivity (technical method) derived as $\mathrm{kg}$ of output per $\mathrm{m}^{3}$ of water Table (7) shows that the highest water productivity was $0.680 \mathrm{~kg} / \mathrm{m}^{3}$ for potatoes, followed by onions at $0.330 \mathrm{~kg} / \mathrm{m}^{3}$, while it was, in descending order, $0.290,0.224,0.210,0.190,0.180,0.172$, 0.153 and $0.132 \mathrm{~kg} / \mathrm{m}^{3}$ for sorghum, maize, vegetables, spices, wheat, chick pea, dry beans, and faba bean respectively, was generally low. On another hand, and from Table (7), it ranged between 5.452 and $2.471 \mathrm{SD} / \mathrm{m}^{3}$ reported for spices and onions respectively.

\subsection{Factors Effecting Irrigation Water Use in the Scheme}

Analysis of efficiency of resource allocation can be accomplished by estimating input response or production functions for various crops and examining resource use through production economics analysis. The data were statistically fitted to several algebraic forms of production functions, a few of which were the linear model, the CobbDouglas, the Quadratic and the Cubic forms (Worku, 1971). The model used in the study is based on Cobb- Douglas production function using the primary data of the field survey 2006 and analyzed with the software program SPSS. The model satisfies some of the specific aims of the research as far as the factors affecting WUE of the field crops of Elzeidab scheme are concerned. In the model wheat was taken as a case for the field crops due to it is biggest area share ( $25 \%$ of the total cultivated area). Wheat productivity ( $\mathrm{kg} / \mathrm{fed}$ ) for season $2005 / 2006$ was taken as dependent variable, while the average of tenants' age, family labour (man-day/fed), distance from home to field $(\mathrm{km})$, hired labour (man-day/fed), distance of farm to source of irrigation $(\mathrm{km})$, number of irrigations (per season), time per irrigation (hour/fed). All the variables had the expected signs with their coefficients passing the t-test at different significant levels. The F-statistics of 15.11 was significant. The model is specified in a linear-linear form; hence, the coefficients of the variables represent the corresponding elasticities that indicate the relative change in water applied to wheat $\left(\mathrm{m}^{3} / \mathrm{fed}\right)$ relative to the change in independent variables. The variables included in the model were found to be significant at different levels as illustrated in Table (8).

Table 5. Assessment of FWUE per season for the crops of the surveyed tenants in Elzeidab scheme.

\begin{tabular}{|c|c|c|c|c|c|c|}
\hline Crop & $\mathrm{CWr}\left(\mathrm{m}^{3} / \mathrm{fed}\right)$ & $\mathrm{CWa}\left(\mathrm{m}^{3} / \mathrm{fed}\right)$ & FWUE-watering & Over- irrigation (\%) & FWUE-season & Over-irrigation (\%) \\
\hline Wheat & 2396 & 3756 & 0.41 & 59 & 0.64 & 36 \\
\hline Faba bean & 1700 & 3708 & 0.41 & 59 & 0.46 & 54 \\
\hline Chickpea & 1746 & 2411 & 0.43 & 57 & 0.72 & 28 \\
\hline Dry bean & 2099 & 3528 & 0.45 & 55 & 0.59 & 41 \\
\hline Onions & 2606 & 8820 & 0.37 & 63 & 0.30 & 70 \\
\hline Spices & 2153 & 3332 & 0.46 & 54 & 0.65 & 35 \\
\hline Vegetable & 2000 & 8820 & 0.34 & 66 & 0.23 & 77 \\
\hline Sorghum & 2171 & 3426 & 0.41 & 59 & 0.63 & 37 \\
\hline Maize & 2590 & 3822 & 0.46 & 54 & 0.68 & 32 \\
\hline Potato & 2870 & 5880 & 0.37 & 63 & 0.49 & 51 \\
\hline Abu 70 & 1697 & 2352 & 0.38 & 62 & 0.72 & 28 \\
\hline
\end{tabular}


Table 7. Determination of yield and productivity per unit water in monetary terms for crops in Elzeidab.

\begin{tabular}{|c|c|c|c|c|c|c|}
\hline Crops & Yield $(\mathrm{kg})$ & $\begin{array}{c}\text { ARTC yield } \\
(\mathrm{kg} / \mathrm{fed})\end{array}$ & Yield Gap \% & $\begin{array}{c}\text { Water productivity } \\
\left(\mathrm{kg} / \mathrm{m}^{3}\right)\end{array}$ & Water price (SD) & $\begin{array}{c}\text { Water productivity } \\
\left(\mathrm{SD} / \mathrm{m}^{3}\right)\end{array}$ \\
\hline Wheat & 675.9 & 2000 & 66 & 0.18 & 13592.59 & 3.619 \\
\hline Faba bean & 488.7 & 1500 & 67 & 0.132 & 14933.33 & 4.027 \\
\hline Chick pea & 414 & 1250 & 67 & 0.172 & 12400 & 5.143 \\
\hline Dry bean & 540 & 12000 & 55 & 0.153 & 13000 & 3.685 \\
\hline Onions & 2880 & 1200 & 76 & 0.33 & 21800 & 2.471 \\
\hline Spices & 630 & $\mathrm{Na}$ & $\mathrm{Na}$ & 0.2 & 18166.67 & 5.452 \\
\hline Vegetable & 1852.5 & 10000 & 81 & 0.21 & 39133.33 & 4.437 \\
\hline Sorghum & 1005.3 & 1700 & 41 & 0.29 & 12313.04 & 3.594 \\
\hline Maize & 855 & 1700 & 50 & 0.224 & 11500 & 3.009 \\
\hline Potato & 4000 & 10000 & 60 & 0.68 & 17000 & 2.891 \\
\hline
\end{tabular}

From Table (8) the age of tenants has got coefficient of 0.26 indicates a one percent increase on tenants' age will decrease the yield by $0.26 \%$, while the numbers of hired and family labours represent a relative increase of $1 \%$ in hired and family labour will cause a relative increase of $0.94 \%$ and $0.40 \%$ in yield of wheat, respectively.

The result shows that the coefficient of home to field variable has got a positive sign explaining an increase of yield by $1.120 \%$ and the coefficient for the distance from source of irrigation to a farm was found as 0.819 indicating a decrease of yield by $0.819 \%$.

Table 8. Regression equation results for wheat crop.

\begin{tabular}{|c|c|c|c|c|}
\hline Variables & $\begin{array}{c}\text { Co- } \\
\text { efficients }\end{array}$ & $\begin{array}{c}\text { Standard } \\
\text { errors }\end{array}$ & t-values & $\begin{array}{c}\text { Level of } \\
\text { Significant } \\
(*)\end{array}$ \\
\hline Intercept & -13.482 & 6.220 & -3.169 & $*$ \\
\hline Age & -0.264 & 0.629 & -2.700 & $*$ \\
\hline $\begin{array}{c}\text { Family labours } \\
\text { (man-day/fed) }\end{array}$ & 0.400 & 0.694 & 4.013 & $* *$ \\
\hline $\begin{array}{c}\text { Hired labours } \\
\text { (man-day/fed) }\end{array}$ & 0.942 & 0.509 & 5.303 & $* * *$ \\
\hline $\begin{array}{c}\text { Home to field } \\
\text { (km) }\end{array}$ & 1.120 & 0.929 & 8.096 & $* * *$ \\
\hline $\begin{array}{c}\text { Farm to source of } \\
\text { irrigation (km) }\end{array}$ & -0.819 & 0.000 & -7.903 & $* * *$ \\
\hline $\begin{array}{c}\text { No. of irrigation } \\
\text { (per season) }\end{array}$ & 0.421 & 0.419 & 2.533 & $*$ \\
\hline $\begin{array}{c}\text { Term of irrigation } \\
\text { (hour/fed) }\end{array}$ & -1.446 & 0.765 & -5.875 & $* * *$ \\
\hline
\end{tabular}

R-square $=0.93$ Adjusted R-square $=0.88$ F-value $=17.87$

* = Significant at $90 \%$ level of probability,

$* *=$ Significant at $95 \%$ level of probability and

$* * *$ = Significant at $99 \%$ level of probability.

The number of irrigation variable of wheat provides a relative increase of $1 \%$ in number of irrigation will cause a relative increase of $0.42 \%$ in yield of wheat. While the time of watering per hour/fed has got a negative coefficient indicating a decrease in wheat productivity by $1.446 \%$. The regression analysis concluded that, the mentioned variables in Table (8) factors affecting wheat productivity and give impressive indicator to assess the on- farm water use efficiency for Elzeidab field crops of River Nile State in season 2005/2006.

\section{Conclusions}

Based on quantitative analysis and obtained results for achieving the main objective of this study implies assessment of social and economical performance of Elzeidab scheme tenants, the results presented here demonstrate that there are differences in irrigation water use relative to the type of the crops under study. The results presented here were interpreted to explain the tenants' behavior towards irrigating their field crops in the area of study, and that might raise numerous questions with some shortcomings in mind. Overall, surface irrigation is dominant system in the RNS and is regarded as having very low efficiency leading to the low FWUE in the majority of the public irrigated schemes; the following policy implication can be adopted.

- Irrigation infrastructures of the scheme limit the rate at which water can be diverted to farms, resulting in runoff, greater carriage water losses and deep percolation. Modern irrigation technologies and other necessary infrastructure improvements are unlikely to occur as a result of limited financial resources, hence, improving finance institutions of the scheme will enable the tenants to improve their resources use and significantly increase their farm returns.

- The awareness about CWR is absent overall the surveyed tenants, probably due limited extension services, thus adoption of a participatory approach by the scheme administrators and tenants to manage irrigation water is a big incentive for tenants to adopt modern water-saving technologies. Thus, promoting tenants' awareness about the importance of water for agriculture, life and environment through efficient structure that can be applied by the extension system.

- All field crops receiving irrigation water in excess of the consumptive use benchmarks (CWR), that the estimated 
on-farm water-use efficiency (FWUE) indicates a wide technological gab between the CWR and the actual applied water reaching $40 \%$ per watering and $56 \%$ for entire the season. The estimated surplus water is sufficient for expanding the scheme's irrigated by $112 \%$. So, the high potential for improvement to save valuable amounts of water that can be used to increase new irrigated areas.

- Intervention of the State is needed to ease irrigationwater availability and improve water-use efficiency either by changing or modernizing the existing irrigation system, adoption of the recommended water use technologies and introduction of modern irrigation technologies.

- As discussed above, the gap of irrigation duration and crop water applied may be a better indicator of water deliveries than the scheme-recorded data if overhauled by research work and the scheme's water accounting procedures do not document the on-farm water use which is regard as important processing to assess the tenants performance towards irrigation water.

- The study unveiled the low value of most of the field crops particularly the strategic ones, wheat and faba beans, so incentives should be provided to make these crops more profitable due to their importance for food security. Relevant policies may include reducing production costs or interventions to purchase them at reasonable prices.

- Water productivity in monetary and physical terms was generally low, the highest for the former was $5.452 \mathrm{SD} / \mathrm{m} 3$ for spices, and for the latter was $0.680 \mathrm{~kg} / \mathrm{m} 3$ for potatoes.

- The main factors affecting FWUE for field crops in the State in season 2005/2006 as measured by wheat productivity were: the tenant age, family labour amount, distance from home to field, hired labour amount, distance of farm to source of irrigation, number of irrigations per season, and duration of irrigation.

\section{REFERENCES}

[1] R.; Van Koppein B. and Shah, T." Aglobal perspective on water scarcity and poverty: Achievements and challenges for water resource management". Colombo, Sri Lanka: International Management Institute. 2000
[2] Bryan, L. and Agabi, S.' Does land tenure system discourage structural adjustment?". Economic esearch Services/ USDA. 2000

[3] ElGamri, T. "Ferrocement for lining canals". Volume (8)No. (1). 2002

[4] Faki, H. H., Idris, M. and Elsir, A. ' Irrigated Benchmark Site Project for Sudan'". 2004

[5] FAO Organization. "Water for food water for life". A Comprehensive assessment of water management in agriculture. 2007

[6] Fetsch, R." Ranching and farming with family numbers". 2005

[7] Internet Website: www.ext.colostate.edu. "The Sudanese Family Life".2009.

http://search.globescope.com/sudan/index.php?page=thesudanese-family-life

[8] John, F. 'Dated at Olympia, Commissioner Employment Security". Washington, July 10. 1964

[9] Lin, J. Y. 'Impact of hybrid rice on input demand and productivity". Agricultural Systems, vol 10. 1994

[10] Rapilian. "Operators principal occupation and number of days worked off-farm". www.ext.vt.edu/pubs/agecon/490-700/part17.pdf. 2007.

[11] Robert, E., Michael, L., Andrew, N. "'Farm size". Paper prepared for volume 3 of the Handbook of Agriculture Economics, University of Sussex. 2004

[12] Rose, M. "Sharing Information with affiliates, Insurance and financial Services Agent"

[13] www.ftc.gov/ptrivacy/glbact/index, html (the GLBA web page). 2007.

[14] Sarah Johnsen. 'New Zealand Farmers' Experiences of Agricultural Restructuring". Contingency Revealed. University of London. 2007

[15] Sheikh, K., H. 'Priorities of Human Research Development in the Water Sector in Islamic Countries". 1995

[16] Worku, D. "The Economic of Water Use 'An Inquiry Into the Economic Behavior of Farmers in West Pakistan"'. Colorado State University. 1971

[17] Xinhaua, A. 'Farmers' Income Levels. New of analysis forecasts". 2001.webmaster@china.org.cn 